\title{
Graphite occurrences in the
}

\section{low-pressure/high-temperature metamorphic belt of the Sierra de Aracena (southern Iberian Massif)}

\author{
M. Rodas $^{1}$, F. J. Luque ${ }^{1}$ *, J. F. Barrenechea ${ }^{1}$, J. C. Fernández-Caliani ${ }^{2}$, A. Miras $^{3}$ and \\ C. FERnÁNDEZ-RodríGueZ
}

1 Departamento de Cristalografía y Mineralogía, Facultad de Geología, Universidad Complutense de Madrid, 28040 Madrid, Spain

2 Departamento de Geología, Facultad de Ciencias Experimentales, Universidad de Huelva, 21819 Palos de la Frontera, Huelva, Spain

3 Departamento de Cristalografía y Mineralogía, Facultad de Química, Universidad de Sevilla, 41071 Sevilla, Spain

\section{ABSTRACT}

Four distinct associations of graphite have been identified in the low-pressure, high-temperature belt of the Sierra de Aracena (SW Spain). Syngenetic occurrences include: (1) stratiform graphite mineralization within a calc-silicate series; (2) disseminated graphite within a terrigenous sequence; and (3) 'restitic' graphite within anatectic tonalites and their enclaves. Epigenetic graphite occurs as (4) veins cross-cutting mafic granulites.

Graphite in all types of occurrences is highly crystalline, with the $c$ parameter close to $6.70 \AA$ A Such $c$ values correspond to temperatures of formation of $\sim 800^{\circ} \mathrm{C}$. The thermal properties of graphite are also typical of well-ordered graphite and provide DTA exothermic maxima ranging from 810 to $858^{\circ} \mathrm{C}$ depending on the mode of occurrence. The differences among the temperatures of formation estimated by graphite geothermometry, the position of the exothermic maximum in the DTA curves, and petrologic geothermometers are discussed in terms of the applicability of graphite geothermometry to granulite-facies rocks. Carbon isotope analysis yields $\delta^{13} \mathrm{C}$ values in the range from -31.6 to $-21.4 \%$ o for syngenetic graphite of types I, II and III attributable to biogenically-derived carbon. The heavier signatures for graphite in vein occurrences $\left(\delta^{13} \mathrm{C}=-17.7\right.$ to $-18.3 \%$ ) with respect to syngenetic graphites suggest that isotopically heavy carbonic species were incorporated into the metamorphic fluids (probably as a consequence of decarbonation reactions of the calc-silicate rocks) from which graphite precipitated into the veins. These fluids were strongly channelled through structural pathways.

KEY WORDS: graphite, calc-silicate rocks, low- $P$ /high- $T$ metamorphism, southern Spain.

\section{Introduction}

GRAPHITE occurrences can be grouped into two categories: (1) syngenetic, formed through the metamorphic evolution of carbonaceous matter dispersed in the sediments; and (2) epigenetic, originating from precipitation of solid carbon from fluids that contain one or more carbonic species (mainly $\mathrm{CO}_{2}$ and $\mathrm{CH}_{4}$ ). The evolution of

\footnotetext{
* E-mail: jluque@eucmax.sim.ucm.es
}

carbonaceous matter during metamorphism (the so-called 'graphitization') involves a series of structural and compositional changes, leading to the formation of fully ordered graphite at the highest metamorphic grades (Grew, 1974; Diessel and Offler, 1975; Wada et al., 1994, among others). On the other hand, precipitation of graphite from fluids is achieved when a C-O-H fluid becomes saturated with respect to this mineral, most frequently as a consequence of decreasing temperature (Luque et al., 1998).

The majority of graphite occurrences worldwide, including most mineralizations, falls within 
the first category. Epigenetic graphite occurrences are less common in nature, although from an economic point of view some of the highest-grade (largest grain size, highest carbon content) veintype commercial graphites result from fluid deposition (e.g. graphite deposits of Sri Lanka; Katz, 1987; Dissanayake, 1994).

This paper deals with graphite occurrences in the low-pressure, high-temperature metamorphic belt of the Sierra de Aracena (SW Spain), where both metamorphic and fluid-deposited graphite have been found. The aim of this paper is to elucidate the geology of graphite occurrences in this area, distinguishing typologies according to lithostratigraphic and structural relationships with respect to the host rocks. Crystallochemical, thermal and isotopic characteristics of graphite from each type of occurrence have been studied in order to constrain the mechanisms of graphite formation. Special attention is paid to potentially mineable occurrences.

\section{Geological setting}

The metamorphic belt of the Sierra de Aracena (Bard, 1969) is a NE-SW oriented narrow band that follows the trend of regional structures at the southernmost border of the Ossa-Morena zone (Fig. 1), in the Iberian Massif (Julivert et al., 1974). The Aracena Metamorphic Belt (AMB) lies in the vicinity of an important suture zone marked by layered metabasites (Acebuches

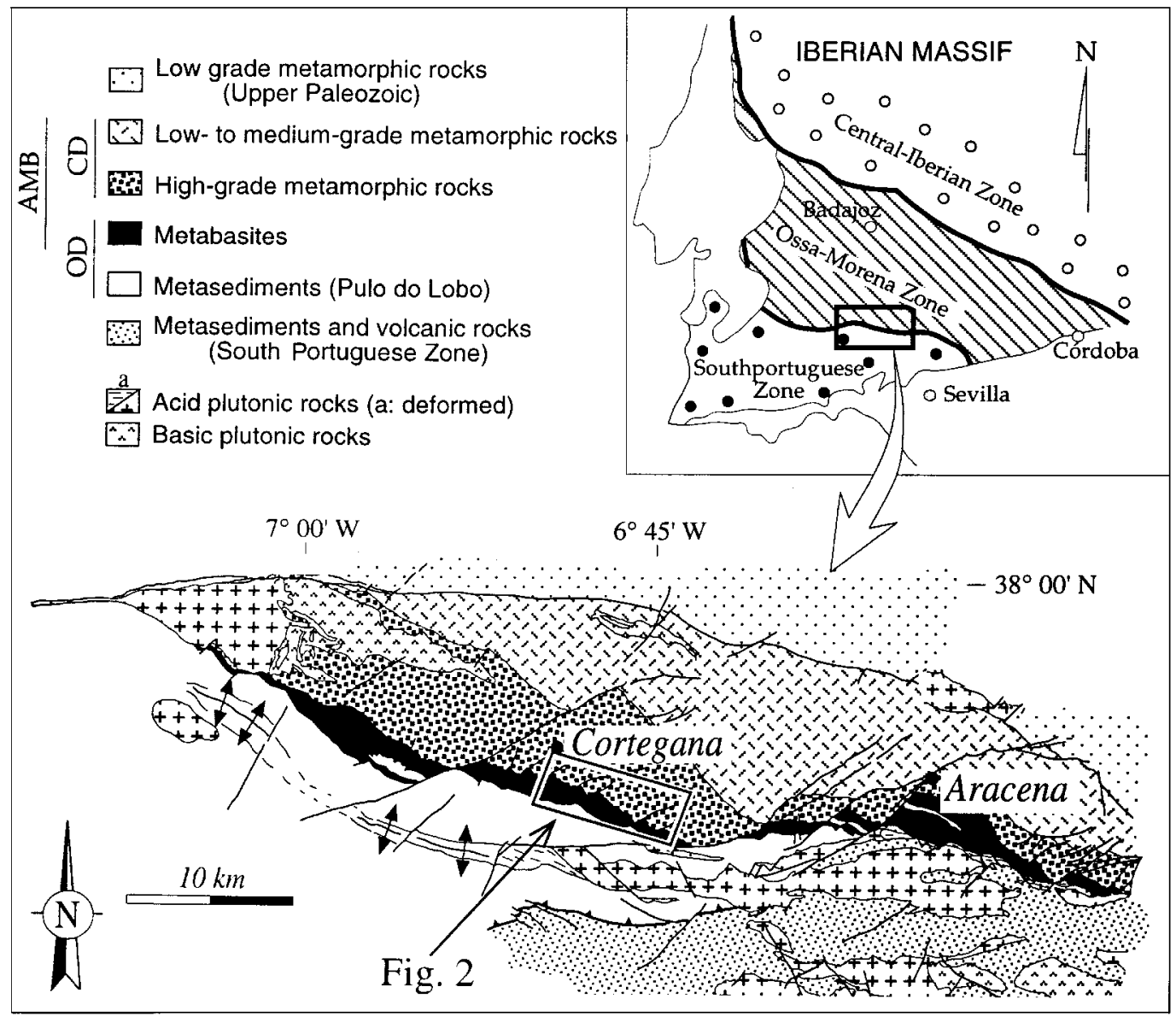

FIG. 1. Location and simplified geological map of the Aracena Metamorphic Belt (AMB) and adjacent areas. CD: Continental Domain. OD: Oceanic Domain. 
amphibolites; cf. Bard, 1969; Bard and Moine, 1979) which constitutes a fragment of an oceanic crust separating two ancient continental blocks (Munhá et al., 1986; Quesada et al., 1994). These metabasites were partially affected by a ductile shear zone (Crespo-Blanc and Orozco, 1988) which marks the southern boundary of the OssaMorena zone.

According to the tectonic setting described above, two main domains have been distinguished in the AMB (Fig. 1) (Castro et al., 1996a,b), with distinctive lithologic, structural and metamorphic characteristics: (1) a continental domain, located in the northern part of the AMB; and (2) an oceanic domain in the southern margin of the belt. The continental domain was intensely folded and metamorphosed during the Variscan orogeny. The thermal peak of metamorphism occurred after the main deformation phase, reaching the granulite facies under low-pressure conditions in the southern part of the continental domain. Temperatures of $\sim 900^{\circ} \mathrm{C}$ have been estimated by El-Biad (in prep.) in metapelites using the GrtCrd-Sil-Qtz equilibrium and other thermometers such as the Grt-Crd exchange reaction and the $\mathrm{Ti}$ content in biotite. These values are the same as those obtained by El-Hmidi (in prep.) from mafic granulites using two-pyroxene geothermometry. Pressure determinations based on the $\mathrm{Al}$ content in hornblende and the use of Pl-Opx-Cpx equilibria (El-Hmidi, in prep.) indicate pressures of $<6 \mathrm{kbar}$. These low-pressure conditions might explain the striking absence of sapphirine and other typical ultra-high temperature mineral phases in the AMB. Similar results were previously obtained by Bard (1969). A low to medium-grade metamorphism affected the northern part of the continental domain. In fact, the strong metamorphic gradient of the continental domain is one of the most salient geological features of this metamorphic belt (Fig. 1). In the high-temperature zone, the stratigraphic succession comprises a Precambrian series of pelitic gneisses, quartzites, and locally anatectic tonalites (Fuente del Oro series; cf. Bard, 1969), and a younger calc-silicate sequence consisting mainly of calc-silicate rocks and leucogneisses with abundant intercalated layers of marbles, quartzites, amphibolites and mafic granulite bodies. The oceanic domain is composed of an homogeneous thick amphibolitic pile derived from tholeiitic basalts of MORB affinity (Bard and Moine, 1979; Castro et al., $1996 b$ ), with minor metadolerites and mafic schists
In brief, petrographic, geochemical and structural data recently reported by Castro et al. (1996a) suggest that the AMB registered the evolution of a low-pressure and high-temperature subduction orogen. In this peculiar tectonic realm, the metamorphic and magmatic effects of subduction have been interpreted by Castro et al. (1996a) as the result of a triple-junction migration along the trench of an ocean-continent subduction zone during Palaeozoic plate convergence.

\section{Types of graphite occurrences}

All graphite occurrences in the AMB are confined to the high-temperature zone of the continental domain (Fig. 2), near the contact with the metabasites of the oceanic domain (FernándezRodríguez et al., 1996).

Four types of graphite occurrences have been distinguished on the basis of their lithostratigraphic and structural relationships with respect to the host rocks (Table 1).

\section{Type I: Stratiform graphite mineralization related to gneisses and quartzites interbedded within the calc-silicate series}

Graphite occurs in parallel layers alternating with leucocratic gneisses and quartzites. These rocks are included within a complex series composed mainly of calc-silicate rocks and wollastonitebearing marbles. The graphite layers are parallel to the main foliation in the country rocks (Fig. 3a) and, although they are generally thin (from a few to several $\mathrm{mm}$ in thickness) locally massive mineralized bodies reaching several metres in thickness are also found. At some sites (Fig. 2), such as La Niña, San Carlos and La Hormiga mines (Jubes and Carbonell, 1918), these graphite deposits were mined in the early 1910s. Deposits of this type contain the largest reserves and best graphite grades in the Aracena Metamorphic Belt. The graphite crystals are coarsely flaky, ranging between 0.25 and $1 \mathrm{~mm}$ in size, and they display a strong preferred orientation, parallel to the main metamorphic foliation in the leucogneisses within which they are hosted.

\section{Type II: Disseminated graphite flakes within gneisses belonging to the Fuente del Oro series}

The graphite-bearing rocks of the Fuente del Oro series consist largely of coarse to medium-grained pelitic gneisses. These gneisses are composed essentially of quartz, alkaline feldspar, muscovite 


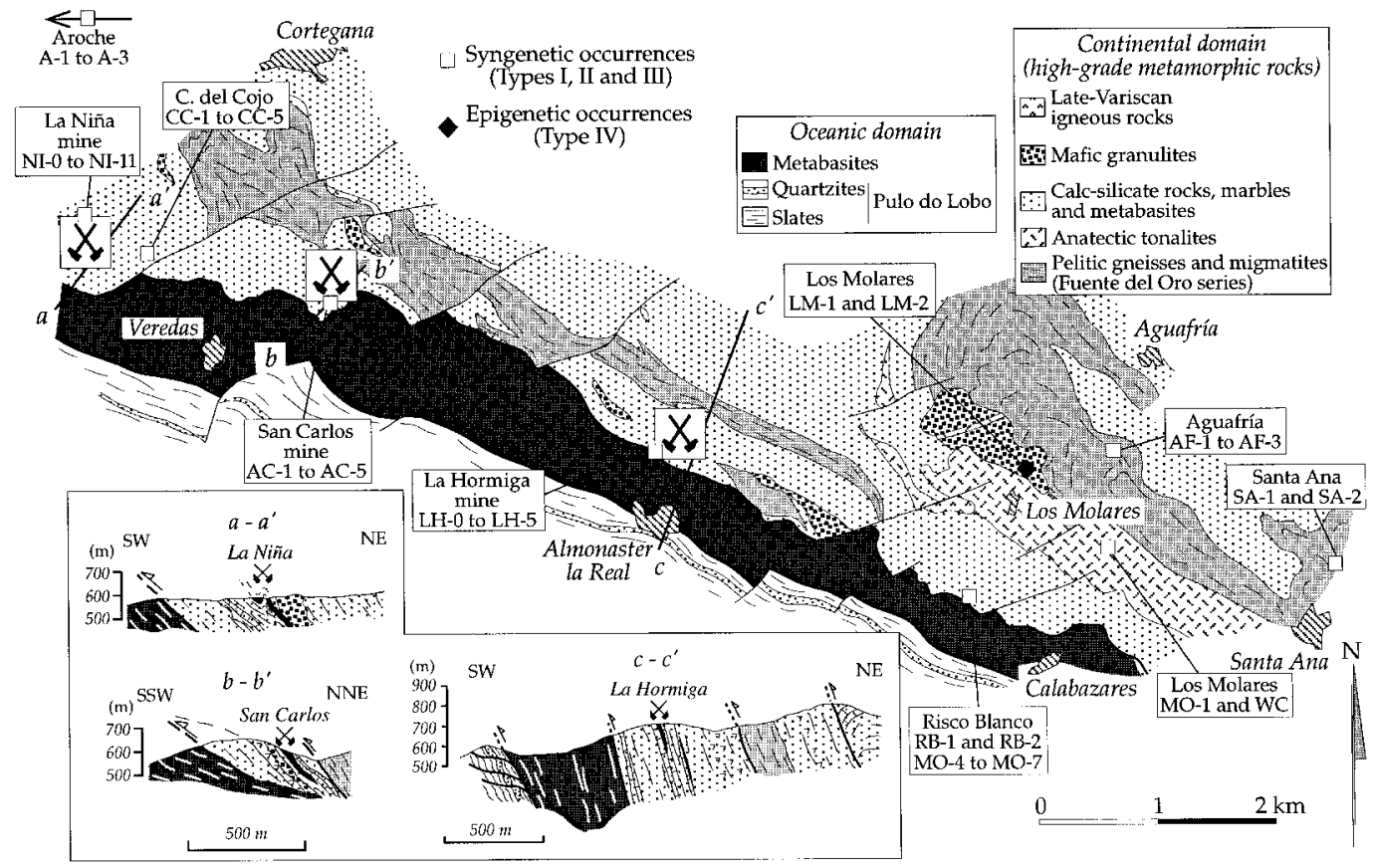

FIG. 2. Geological map of the study area showing the locations of graphite occurrences and sampling points. Crosssections of old graphite mines are also shown.

and biotite with minor amounts of plagioclase, zircon, rutile and graphite. In general, graphite occurs in disseminated tiny flakes parallel to the gneissic foliation (Fig. $3 b$ ), with a crystal size up to $0.05 \mathrm{~mm}$. In some cases, coarse- to mediumgrained quartzites appear to show a very fine layering marked by graphite-rich layers, together with oriented micaceous minerals defining a rough schistosity parallel to the graphite layers.

\section{Type III: Graphite associated with anatectic tonalites and their restitic enclaves}

Graphite occurs either as irregular patches (up to a few $\mathrm{cm}$ in thickness) enclosed within the anatectic tonalites or as fine flakes disseminated within their restitic enclaves. The anatectic tonalites show typical igneous textures and include quartz, alkaline feldspar, Na-rich plagioclase, biotite, sillimanite, cordierite and a variety of accessory minerals, such as muscovite, zircon, apatite and rutile. Graphite occurs with laminar and rounded morphologies (Fig. 3c). Disseminated flakes of graphite in quartzitic restites within the tonalites show no preferred orientation.

\section{Type IV: Graphite veins}

Graphite appears in narrow and irregular mmthick veins cross-cutting mafic granulites. The granulitic host-rock shows coarse-grained granoblastic textures, and it is composed of diopsiderich clinopyroxene, brownish hornblende and plagioclase $\left(\mathrm{An}_{50}\right)$, with subordinate amounts of biotite, zircon, apatite, chlorite, sericite, magnetite and hematite. The clinopyroxene occurs partially replaced by amphibole which suggests that the granulites underwent a significant retrograde metamorphism to amphibolite facies. The graphite vein distribution is not only tectonically controlled but it also depends on textural characteristics, as evidenced by the occurrence of intracrystalline veins parallel to the cleavage planes of the amphibole (Fig. $3 d$ ).

\section{Methods of investigation}

Field work included geological mapping of the mineralized areas at a scale of 1:10,000 and collection of 49 representative samples at different locations in the continental domain of the AMB, which were examined by transmitted 


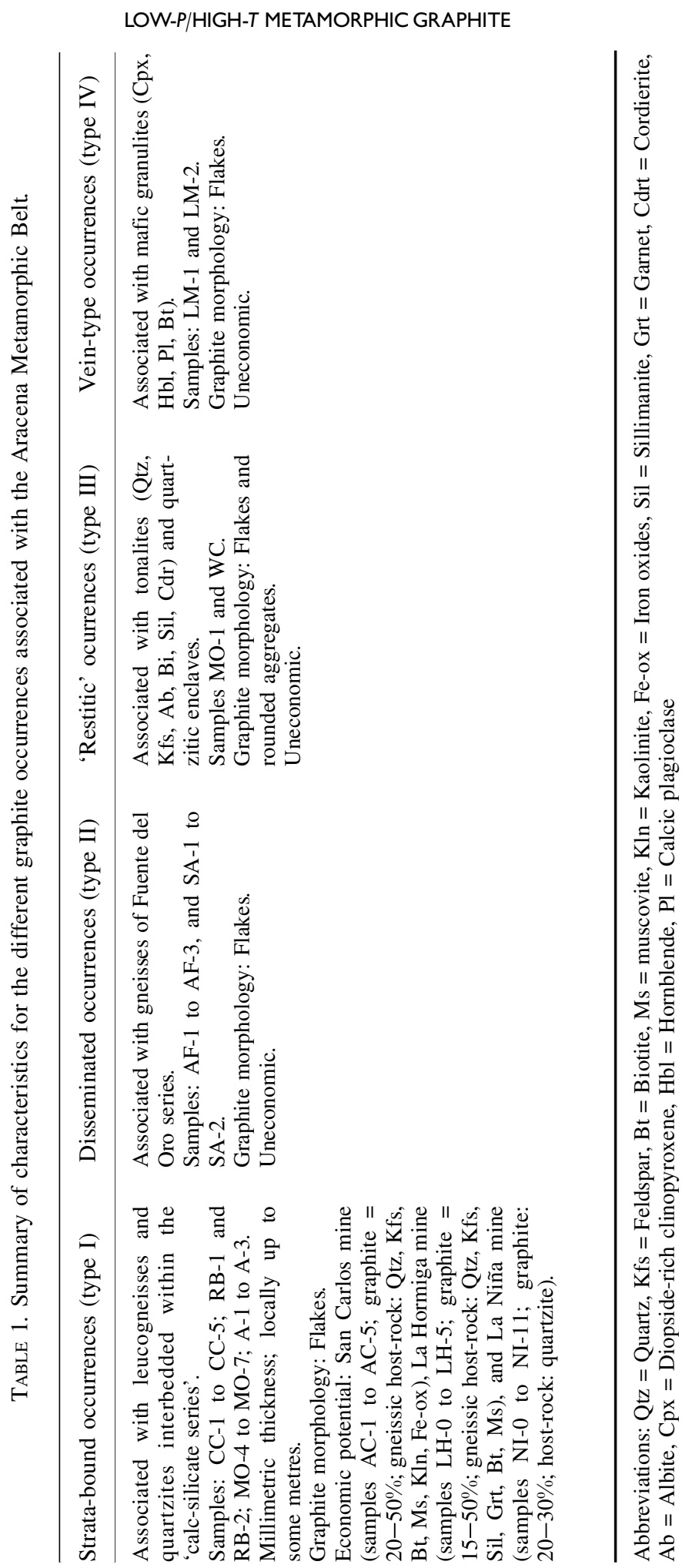



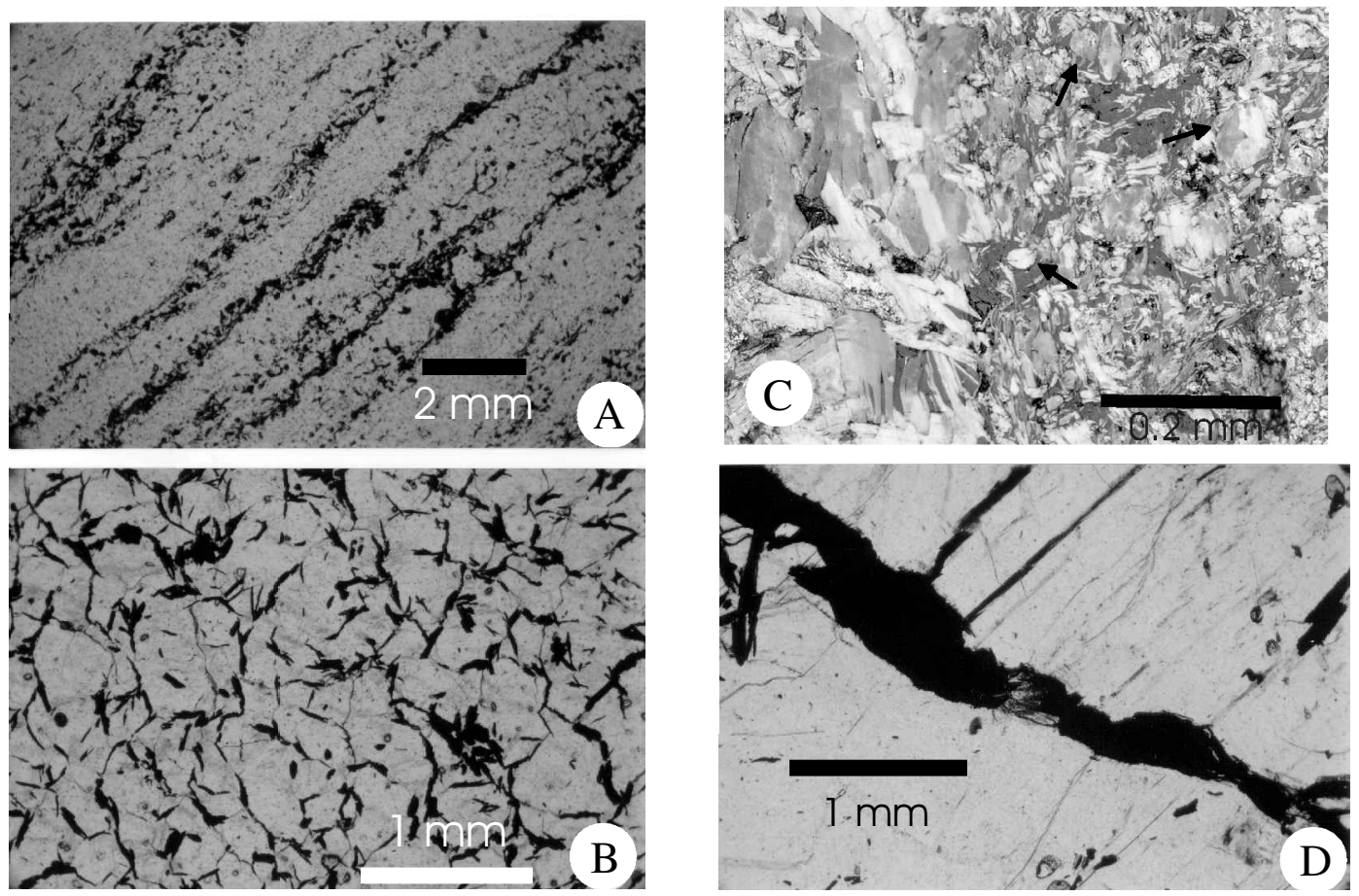

FIG. 3. (a) Transmitted light photomicrograph of graphite from a type I occurrence. Note that the graphite flakes are parallel to the foliation of the gneissic rock. (b) Transmitted light photomicrograph of disseminated graphite laths in a sample from a type II occurrence. (c) Reflected light photomicrograph of 'restitic' graphite in a cordierite-bearing nebulitic tonalite (type III occurrence). Note the coexistence of graphite flakes and rounded morphologies (some of them indicated by arrows). (d) Transmitted light photomicrograph of a graphite vein in a mafic granulite (type IV occurrence). Note that the cleavage of the host amphibole also controls graphite distribution.

and reflected light microscopy for mineral identification and petrographic description.

The structural characteristics and chemical composition of graphite as well as its thermal behaviour were studied on concentrates obtained by flotation in distilled water, as described by Luque et al. (1993). The structural study of graphite was performed by X-ray diffraction (XRD) in a Philips PW 1729 powder diffractometer equipped with a graphite monochromator, using $\mathrm{Cu}-K \alpha$ radiation at $40 \mathrm{kV}$ and $30 \mathrm{~mA}$, a step size of $0.01\left({ }^{\circ} 2 \theta\right)$, time per step of $0.5 \mathrm{~s}$, scan speed of $0.02(2 \theta / \mathrm{s})$, and receiving slit of 0.1 . Samples were run from 20 to $65^{\circ} 2 \theta$. Silicon was used as an internal standard.

The thermal properties of graphite were determined by simultaneous recording of differential thermal analysis (DTA) and thermogravimetric (TG) curves, using a Stanton STA 781 apparatus. The DTA curves were obtained by heating the sample at $10^{\circ} \mathrm{C} / \mathrm{min}$ in the range 20 to $1000^{\circ} \mathrm{C}$, with a continuous air supply of $50 \mathrm{ml} / \mathrm{min}$. Under these analytical conditions, the exothermic maximum due to carbon combustion is accompanied by a weight loss (as recorded in the TG curve) whose magnitude depends on the carbon content of the graphite sample. Estimated carbon contents based on the TG curves were verified by elemental analysis of the samples, using a Perkin-Elmer CHN 2400 gas analyser for the determination of $\mathrm{C}, \mathrm{H}$ and $\mathrm{N}$. Elemental analyses were carried out by heating the sample at $950^{\circ} \mathrm{C}$, followed by reduction with $\mathrm{Cu}$ at $650^{\circ} \mathrm{C}$.

Geochemical characterization included determination of the carbon isotope ratio on bulk graphite concentrates by extraction techniques and mass spectrometry, using a VG Micromass gas-source apparatus at the Geochron Laboratories (Massachussetts, USA). Analytical procedures have been described in a previous 
paper (Barrenechea et al., 1997). The results are reported in the conventional $\delta$ notation relative to the PDB standard. The anlytical precision of the method, including both sample preparation and analysis, was $\sim \pm 0.2 \%$.

\section{Analytical results}

Table 2 summarizes the structural and thermal data of graphite in the four types of occurrences in the AMB. The XRD patterns correspond to highly crystalline hexagonal graphite, showing sharp and symmetric (002) peaks with a $d_{002}$ spacing ranging from 3.348 to $3.352 \AA$ (i.e. $c=2 d_{002}=$ 6.696 to $6.704 \AA)$. The intensity ratios of $(002)$ to (004) reflections $\left(I_{002} / I_{004}\right)$ are also compatible with those of fully ordered graphite (Luque $e t$ al., 1992). In addition, crystallite sizes along the $c$-axis $(L c)$ determined for selected samples (following the method proposed by Tagiri, 1981) exceed $1000 \AA$, which confirms the high crystallinity of graphite in all types of occurrences.

The position of the exothermic maximum in the DTA curve of graphite from type I occurrences (Table 2 and Fig. 4) ranges from 775 to $832^{\circ} \mathrm{C}$, with an average value of $\sim 810^{\circ} \mathrm{C}$. Graphite from occurrences of types II, III and IV has slightly higher temperatures of combustion (close to $850^{\circ} \mathrm{C}$ ), as shown in Table 2. Elemental analysis of graphite from type I occurrences yield C contents ranging from $\sim 80$ to $90 \mathrm{wt} \% \%$ (Table 3). The $\mathrm{H}$ and $\mathrm{N}$ contents as well as the atomic $\mathrm{H} / \mathrm{C}$ ratios (Table 3) are low, as expected for highgrade metamorphic graphite.

Carbon isotope ratios for selected graphite samples are listed in Table 4, and plotted in Fig. 5. Graphite from type I mineralization has isotopic ratios ranging between -21.4 and $-28.4 \%$ ( $-26.4 \%$ average). Graphite from type II occurrences has slightly lighter $\delta^{13} \mathrm{C}$ values, with an average of $-28.0 \%$. Graphite from restite

TABLE 2. Structural (XRD) and thermal characteristics of graphite from the different types of occurrences.

\section{XRD}

DTA
Type II

(samples: AF-1, AF-2, SA-2)

Type III

(samples: MO-1, WC)

Type IV

(samples: LM-1, LM-2)

$$
\begin{aligned}
& c=6.696-6.708 \AA \\
& \text { average }=6.700 \AA \\
& I_{\mathrm{OO} 2} / I_{\mathrm{OO} 4}=18-35 \\
& \text { average }=25 \\
& T=750-800^{\circ} \mathrm{C}^{*} \\
& n=18
\end{aligned}
$$

$c=6.700-6.704 \AA$

average $=6.703 \AA$

$I_{002} / I_{004}=13-18$

average $=15$

$T=750-800^{\circ} \mathrm{C}^{*}$

$n=3$

$c=6.704 \AA$

$I_{002} / I_{004}=30$

$T=750^{\circ} \mathrm{C}^{*}$

$n=2$

$c=6.698-6.702 \AA$

average $=6.700 \AA$

$I_{002} / I_{004}=12-16$

average $=14$

$T=770-780^{\circ} \mathrm{C}^{*}$

$n=2$

\author{
Exothermic maximum $=775-832^{\circ} \mathrm{C}$ \\ average $=810^{\circ} \mathrm{C}$ \\ $T_{\mathrm{i}}=516-537^{\circ} \mathrm{C}$ \\ average $=527^{\circ} \mathrm{C}$ \\ $T_{\mathrm{f}}=915-946^{\circ} \mathrm{C}$ \\ average $=932^{\circ} \mathrm{C}$ \\ $n=9$
}

Exothermic maximum $=847^{\circ} \mathrm{C}$

$T_{\mathrm{i}}=610^{\circ} \mathrm{C}$

$T_{\mathrm{f}}=944^{\circ} \mathrm{C}$

$n=1$

Exothermic maximum $=852^{\circ} \mathrm{C}$

$T_{\mathrm{i}}=626^{\circ} \mathrm{C}$

$T_{\mathrm{f}}=951^{\circ} \mathrm{C}$

$n=1$

Exothermic maximum $=858^{\circ} \mathrm{C}$

$T_{\mathrm{i}}=630^{\circ} \mathrm{C}$

$T_{\mathrm{f}}=1000^{\circ} \mathrm{C}$

$n=1$

$n=$ number of analysed samples

* Temperatures calculated on the basis of the $c$ parameter according to the geothermometrical estimation of Shengelia et al. (1979) 


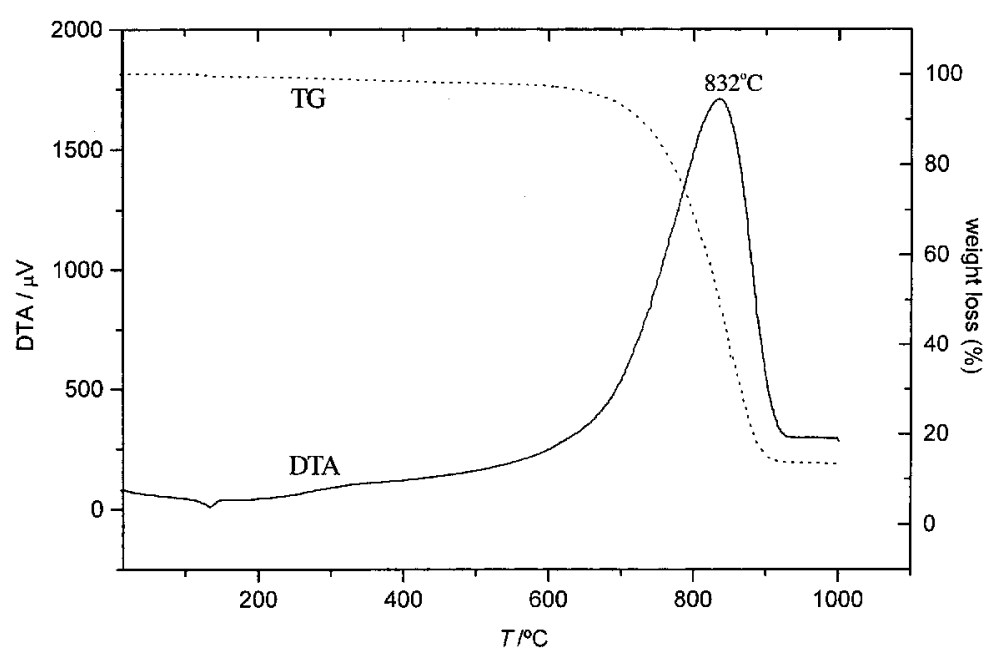

FIG. 4. Differential thermal analysis (DTA) and thermogravimetric (TG) curves for graphite from a type I occurrence (San Carlos mine, sample AC-4), showing the temperature of the maximum of the exothermic effect and the weight loss $(87.47 \%)$ due to the combustion of carbon.

occurrences (type III) has a fairly homogeneous signature, close to $-24.7 \%$. For the studied set of samples, the heaviest isotopic values correspond to the vein-type graphite (type IV), which ranges from $\delta^{13} \mathrm{C}=-17.7$ to $-18.3 \%$.

\section{Discussion}

The four types of graphite occurrences of the Aracena Metamorphic Belt reflect two different processes of graphite formation. The occurrences of types I, II and III result from the evolution of organic matter at high-grade metamorphic conditions, as evidenced by their geological and mineralogical characteristics. According to regional correlations with lower grade areas (Bard, 1969), the most conspicuous graphite mineralizations in the AMB (type I) were originally deposited during the Upper Precambrian-Cambrian as lidites, sandstones and clayey sediments very enriched in carbonaceous matter, within a carbonate sequence. The high concentration of organic matter in these sediments could be tentatively ascribed to the result of sedimentation in a continental shelf under reducing conditions, related to a high organic productivity in anoxic bottoms, which favoured the preservation of this carbonaceous matter.

TABLE 3. Elemental analyses of selected graphite samples from type I occurrences. Location of samples shown in Fig. 2.

\begin{tabular}{lcccc}
\hline Sample & Carbon & Hydrogen & Nitrogen & H/C atomic ratio \\
\hline A-2 & 79.42 & 0.37 & 0.17 & 0.056 \\
AC-2 & 89.60 & 0.10 & 0.07 & 0.013 \\
AC-4 & 86.22 & 0.22 & 0.12 & 0.031 \\
CC-5 & 89.16 & 0.12 & 0.08 & 0.016 \\
LH-2 & 85.02 & 0.19 & 0.12 & 0.027 \\
LH-4 & 82.16 & 0.19 & 0.04 & 0.028 \\
MO-4 & 83.54 & 0.24 & 0.11 & 0.034 \\
NI-2 & 85.18 & 0.10 & 0.07 & 0.027 \\
NI-10 & 84.81 & 0.19 & & \\
& & & & \\
\hline
\end{tabular}


TABLE 4. Isotopic composition of graphite samples from the different types of occurrences. Location of samples shown in Fig. 2.

$\delta^{13} \mathrm{C} \%$
Type/sample

Type I

$\begin{array}{ll}\text { A-3 } & -27.8 \\ \text { AC-4 A } & -27.9 \\ \text { AC-4 B } & -27.9 \\ \text { LH-3 B } & -26.0 \\ \text { CC-5 } & -21.4 \\ \text { MO-4 } & -25.0 \\ \text { NI-2 } & -28.4 \\ \text { NI-8 } & -27.2 \\ \text { Average } & -26.4\end{array}$

Type II

SA-2 A $\quad-26.4$

SA-2 B $\quad-26.2$

AF-1 -31.6

Type III

Average $\quad-28.0$

$\begin{array}{ll}\text { MO-1 A } & -24.8 \\ \text { MO-1 B } & -24.7 \\ \text { MO-1 C } & -24.7 \\ \text { Average } & -24.7\end{array}$

Type IV

LM-1 C $\quad-17.7$

LM-2 C-1 $\quad-18.2$

LM-2 C-2 $\quad-18.3$

Average $\quad-18.1$

Graphite-bearing gneisses and quartzites from type II occurrences derived from high-temperature metamorphism of an older sequence of pelitic sediments enriched in organic carbon, whose lowgrade metamorphic counterparts crop out at the core of anticlinorial structures in the northern part of the AMB (La Umbría Series; cf. Bard, 1969). On the other hand, 'restitic' graphite in cordieritebearing tonalites (type III occurrences) resulted from the partial melting of the original clayey sediments of La Umbría Series (cf. Bard, 1969). These rocks therefore represent the final products of the ultra-high temperature metamorphism that affected the southern margin of the Continental Domain.

Vein-type graphite in mafic granulites (type IV occurrences) is clearly distinct from the previously described syngenetic occurrences. These mafic granulites are orthoderivate rocks of boninite affinity resulting from primary magmatism in the subduction zone during Palaeozoic times, and that later underwent metamorphic temperatures close to $900^{\circ} \mathrm{C}$ (Castro et al., 1996a). The occurrence of graphite veins in these granulitic rocks involves the problem of the role of carbonic fluids (that is, $\mathrm{CO}_{2}$-rich fluids; Glassley, 1982) in the granulite metamorphism. The anhydrous conditions required for granulite formation can be attained either by dry, vapourfree metamorphism (e.g. Lamb and Valley, 1984; Yardley and Valley, 1997) or through the input of internally- (Hansen et al., 1987) or externallyderived $\mathrm{CO}_{2}$-rich fluids (Newton et al., 1980; Farquhar and Chacko, 1991; Wada and Santosh, 1995). External sources of $\mathrm{CO}_{2}$ include magmatic, mantle-derived fluids (Newton et al., 1980; Farquhar and Chacko, 1991; Satish-Kumar and Santosh, 1998), metamorphic decarbonation reactions (Hapuarachchi, 1977; Silva, 1987), and devolatilization reactions of organic matter (Dissanayake, 1994). In addition, the debate still continues on the transfer mechanisms of such $\mathrm{CO}_{2}$ fluids into the crust. The fluid flow mechanisms can be grouped into two models: (1) pervasive flow (Lamb and Valley, 1984, 1985); and (2) channelized flow through structural pathways (Katz, 1987; Santosh and Wada, 1993a; SatishKumar and Santosh, 1998). Additional evidence for the participation of carbonic fluids during granulite metamorphism comes from the presence of $\mathrm{CO}_{2}$ fluid inclusions in minerals of granulitic assemblages (e.g. Touret, 1971; Jackson et al., 1988; Vry et al., 1988; Satish-Kumar and Santosh, 1998).

Bearing in mind the above considerations, the graphite veins that occur in the Aracena Metamorphic Belt indicate the circulation of $\mathrm{CO}_{2}$-rich fluids through these rocks. In this case, graphite was formed by deposition from channelized carbon-bearing fluids, as evidenced by their field relationships (cross-cutting contacts, and structural control of vein distribution). Furthermore, the preservation of a biogenic signature in the disseminated graphite within the metapelitic lithologies does not favour the hypothesis of a pervasive fluid flow. Finally, despite the small scale of the veins in this area, such carbonic fluids would be comparable to those responsible for large vein-type graphite deposits in granulite terranes of Sri Lanka and India (Luque and Rodas, 1999).

As noted previously, graphite in all types of occurrences is highly crystalline. The $d_{002}$ 


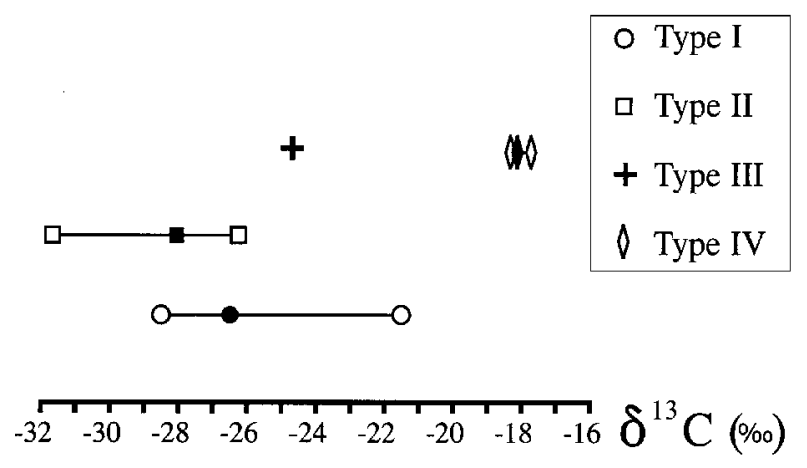

FIG. 5. $\delta^{13} \mathrm{C}$ values of graphite from stratiform (type I), disseminated (type II), 'restitic' (type III), and vein (type IV) occurrences. Tie-lines connect the extreme values for each type of occurrence (see Table 4). Average values are plotted as solid symbols.

spacings for graphite of types I and II are in good agreement with those reported in the literature for graphite in high-grade metamorphic rocks (e.g. Kwiecinska, 1980; Wada et al., 1994; Radhika et $a l$., 1995). In addition, XRD data for restitic graphite (type III) are similar to those reported by Kanaris-Sotiriou (1997) for graphite in anatectic dacites. Graphite in vein-type occurrences (type IV) also has the structural features of highly crystalline graphite, typical of natural fluiddeposited occurrences (Luque et al., 1998, and references therein). As recently reported by Pasteris and Luque (1997) and Luque and Rodas (1999), such structural characteristics are influenced by a number of factors, such as the $T$ and $P$, the source of carbon and kinetic constraints.

According to the XRD results, and by using the graphite geothermometry estimation based on the $c$ parameter proposed by Shengelia et al. (1979), the temperature of formation for graphite in all types of occurrences ranges from 750 to $800^{\circ} \mathrm{C}$ (Table 2). Such temperatures are $\sim 100^{\circ} \mathrm{C}$ lower than those estimated by Castro et al. (1996a) for the host-rocks of the graphite occurrences on the basis of element partitioning between coexisting minerals. Differences between temperatures of formation from both geothermometric methods may reflect the limitation of the $c$ parameter of graphite as a geothermometer at temperatures above $800^{\circ} \mathrm{C}$. The application of graphite as a geothermometer is based upon the progressive decrease in the $c$ parameter with increasing crystallinity as temperature rises (Shengelia et al., 1979; Tagiri, 1981; Luque et al., 1993). However, the results obtained by Wada et al. (1994) clearly indicate that the $c$ parameter is not sensitive to crystallinity changes once graphite has attained the $d_{002}$ spacing corresponding to the ideal structure $\left(d_{002}=3.35 \AA\right)$, although the crystallite size along the stacking direction $(L c)$ becomes larger with increasing crystallinity. These data show that a closer arrangement of the layers of carbon atoms along the stacking direction is physically unlikely in the graphite structure. In fact, the lowest $d_{002}$ spacings reported for both metamorphic (Kwiecinska, 1980) and fluid-deposited graphite (Luque et al., 1998) are in the range 3.350-3.348 A. Therefore, temperatures estimated by graphite geothermometry in the present study should be regarded as minimum temperatures, since the $c$ values for graphite in the occurrences of the AMB correspond to the upper limit of the calibration.

The position of the exothermic maximum in DTA curves correlates with the temperature at which graphite was formed (Diessel and Offler, 1975; Kwiecinska, 1980; Wada et al., 1994), although it is also influenced by the elemental composition of graphite (Luque et al., 1998). According to the ranges given by Kwiecinska (1980), the temperatures recorded for graphite from the different types of occurrences in the AMB are close to the limit between amphibolitefacies and granulite-facies metamorphic rocks. Individual DTA temperatures of carbon combustion are therefore closer to those estimated by petrologic geothermometers.

Elemental analyses of graphite concentrates from type I occurrences (Table 3 ) show typically high $\mathrm{C}$ contents and very low contents of heteroatoms $(\mathrm{H}, \mathrm{N})$, which agree with their fully ordered nature. The $\mathrm{H} / \mathrm{C}$ atomic ratios are close to 
those given by different authors (e.g. Kwiecinska, 1980; Itaya, 1981) for graphite in high-grade metamorphic rocks.

The carbon isotope ratio $\left({ }^{13} \mathrm{C} /{ }^{12} \mathrm{C}\right)$ is a useful geochemical tool for interpreting the origin of graphite, since the main sources of $\mathrm{C}$ (organic matter, carbonates and igneous carbon derived from the mantle) are characterized by different isotopic ranges. Graphite from syngenetic occurrences (types I, II and III) has a light carbon isotope signature, falling within the typical range of biogenically-derived graphite (HahnWeinheimer and Hirner, 1981; Weis et al., 1981; Crawford and Valley, 1990).

In contrast, graphite from type IV occurrences (veins) shows a distinctly heavier signature $(-18.1 \%$ on average, i.e. from 6 to $10 \%$ heavier than the average signatures for graphite in syngenetic occurrences). Heavier carbon isotopic signatures for vein-type graphite in granulitic areas than for graphite in the metasedimentary host-rocks have also been reported in the literature (Vry et al., 1988; Farquhar and Chacko, 1991; Santosh and Wada, 1993b; Wada and Santosh, 1995). It is well-known that increasing metamorphic temperatures cause devolatilization of carbonaceous matter as well as decarbonation reactions in carbonate lithologies. During devolatilization of carbonaceous matter, isotope fractionation is dependent upon several parameters (Poulson, 1996) but residual graphite is usually enriched in ${ }^{13} \mathrm{C}$, and carbonic species enriched in the lighter isotope are released (Hoefs and Frey, 1976; Rumble et al., 1986; Crawford and Valley, 1990). If carbon was incorporated into metamorphic fluids by such a mechanism, lighter $\delta^{13} \mathrm{C}$ values should be expected for veintype graphite with respect to graphite from syngenetic occurrences. The isotopically heavier $\mathrm{C}$ of graphite from the epigenetic occurrences described here probably resulted from mixing of carbonic species with significantly distinct isotopic signatures, ${ }^{13} \mathrm{C}$-depleted methane coming from the devolatilization of organic matter and ${ }^{13} \mathrm{C}$-enriched $\mathrm{CO}_{2}$ released through decarbonation of the calc-silicate lithologies (marbles and amphibolites). These processes of devolatilization and decarbonation would be associated with the granulite-facies metamorphism that affected the study area. Therefore, the source of $\mathrm{CO}_{2}$ would be local, although a deep-seated, magmatic origin of carbon should not be discarded, because such carbon would also be enriched in the heavy isotope (Weis et al., 1981; Mattey, 1987; Luque et al., 1999).

In addition to these isotopic shifts between syngenetic and epigenetic graphite, small isotopic differences even exist among graphite samples from the metamorphic occurrences (types I, II and III). Thus, the difference between the average $\delta^{13} \mathrm{C}$ for type I and type II graphite is $\sim 1.6 \%$ (up to $3.2 \%$ for the lightest values), although their isotopic signatures fall within the reported ranges for most Precambrian and Phanerozoic biogenically-derived graphites (Schoell and Wellmer, 1981). The isotopic shift related to the thermal evolution of the carbonaceous matter during metamorphism, including Precambrian materials, is well documented (Des Marais et al., 1992; Naraoka et al., 1996). The observed differences in the carbon isotope ratio for graphite from type I and II occurrences are probably not primarily related to the effect of temperature on the isotopic fractionation during metamorphism as both types were affected by similar granulite-facies metamorphic conditions. Moreover, the isotopic signatures for graphite in both types of occurrences seem to indicate that any significant isotopic fractionation did not occur during the metamorphic event, or that the precursor carbonaceous matter had anomalously light $\delta^{13} \mathrm{C}$ values. In this context, the heaviest isotopic signature found in one graphite sample from a type I occurrence (-21.4 $\%$ ) may reflect local isotope fractionation. Schidlowski et al. (1979) and Arneth et al. (1985) have suggested that the magnitude of the isotopic shift during metamorphism in gneissic lithologies within calc-silicate sequences is related to the modal abundance of newly formed $\mathrm{Ca}-\mathrm{Mg}$ silicates. As a consequence of the arguments above, the observed differences in the carbon isotope ratios for graphite in type I and II occurrences might be attributable to original differences between Precambrian (type II) and Cambrian (type I) organic precursors or, alternatively, to the influence of the different lithology of their host-rocks (gneisses and quartzites within a calc-silicate sequence, and gneisses within a terrigenous series, respectively)

Finally, 'restitic' graphite from type III occurrences shows an homogeneous isotope signature, slightly heavier than the average values for graphite from type I and II. Such an isotopic ratio reveals a biogenic origin and agrees with the residual character of this graphite, which is hosted by a rock that underwent partial melting, leading to a slightly higher isotopic fractionation. 


\section{Conclusions}

Field relationships as well as mineralogical and isotopic data presented in this paper have allowed us to establish four types of graphite occurrences in the AMB. Occurrences of types I, II and III are syngenetic and were formed through granulitefacies metamorphism of carbonaceous matter. Vein-type epigenetic graphite (type IV) was deposited from C-bearing fluids generated during metamorphism. The only occurrences with potential economic interest are those of type I.

Graphite in all types of occurrences shows high crystallinity as revealed by the XRD study and thermal properties. The differences observed among the temperatures of formation estimated by graphite geothermometry, the position of the exothermic maximum in the DTA curves, and petrologic geothermometers are indicative of the limitations of the $c$ parameter of graphite as a geothermometer at the temperatures of granulitefacies metamorphism, since such parameter is not sensitive to record structural changes above $c$. $800^{\circ} \mathrm{C}$.

Carbon isotope ratios of graphite from the four types of occurrences correspond to biogenicallyderived carbon. Nevertheless, the higher $\delta^{13} \mathrm{C}$ for graphite from type IV mineralization suggests the incorporation of isotopically-heavy carbonic species into the metamorphic fluids, probably evolved from decarbonation reactions in the calcsilicate rocks.

\section{Acknowledgements}

This study has been supported by the Spanish DGICYT through projects PB93-0064 and PB980836. The paper was improved through the criticism of Prof. J.L.R. Touret. The authors also express their gratitude to Dr R. Rojas for technical assistance during the thermal study of graphite samples.

\section{References}

Arneth, J.D., Schidlowski, M., Sarbas, B., Goerg, U. and Amstutz, G.C. (1985) Graphite content and isotopic fractionation between calcite-graphite pairs in metasediments from the Mgama Hills, Southern Kenya. Geochim. Cosmochim. Acta, 49, 1553-60.

Bard, J.P. (1969) Le métamorphisme régional progressif de Sierra de Aracena en Andalousie occidentale
(Espagne). Thèse d'État, Univ. Montpellier.

Bard, J.P. and Moine, B. (1979) Acebuches amphibolites in the Aracena Hercynian metamorphic belt (southwest Spain): geochemical variations and basaltic affinities. Lithos, 12, 271-82.

Barrenechea, J.F., Luque, F.J., Rodas, M. and Pasteris, J.D. (1997) Vein-type graphite in Jurassic volcanic rocks of the External Zone of the Betic Cordillera, southern Spain. Canad. Mineral., 35, 1379-90.

Castro, A., Fernández, C., De la Rosa, J.D., MorenoVentas, I., El-Hmidi, H., El-Biad, M., Bergamín, J.F. and Sánchez, N. (1996a) Triple-junction migration during Paleozoic plate convergence: the Aracena metamorphic belt, Hercynian massif, Spain. Geol. Rundsch., 85, 180-5.

Castro, A., Fernández, C., De la Rosa, J.D., MorenoVentas, I. and Rogers, G. (1996b) Significance of MORB-derived amphibolites from the Aracena Metamorphic Belt, Southwest Spain. J. Petrol., 37, 235-60.

Crawford, W.A. and Valley, J.W. (1990) Origin of graphite in the Pickering gneiss and the Franklin marble, Honey Brook Upland, Pennsylvania Piedmont. Geol. Soc. Amer. Bull., 102, 807-11.

Crespo-Blanc, A. and Orozco, M. (1988) The Southern Iberian Shear Zone: a major boundary in the Hercynian folded belt. Tectonophysics, 148, 221-7.

Des Marais, D.J., Strauss, H., Summons, R.E. and Hayes, J.M. (1992) Carbon isotope evidence for the stepwise oxidation of the Proterozoic environment. Nature, 359, 605-9.

Diessel, C.F.K. and Offler, R., 1975, Change in physical properties of coalified and graphitised phytoclasts with grade of metamorphism. Neues Jahrb. Mineral. Mh., 1, 11-27.

Dissanayake, C.B. (1994) Origin of vein graphite in high-grade metamorphic terranes. Role of organic matter and sediment subduction. Mineral. Deposita, 29, 57-67.

Farquhar, J. and Chacko, T. (1991) Isotopic evidence for involvement of $\mathrm{CO}_{2}$-bearing magmas in granulite formation. Nature, 354, 60-3.

Fernández-Rodríguez, C., Fernández Caliani, J.C., Miras, A., Barrenechea, J.F., Luque F.J. and Rodas, M. (1996) Nuevos datos geológicos sobre las mineralizaciones de grafito de la Banda Metamórfica de Aracena, Huelva (Macizo Ibérico Meridional). Geogaceta, 20 (7), 1576-7.

Glassley, W. (1982) Fluid evolution and graphite genesis in the deep continental crust. Nature, 295, 229-31.

Grew, E.S. (1974) Carbonaceous material in some metamorphic rocks of New England and other areas. J. Geol., 82, 50-73.

Hahn-Weinheimer, P. and Hirner, A. (1981) Isotopic evidence for the origin of graphite. Geochem. J., 15, 9-15. 
Hansen, E.C., Janardhan, A.S., Newton, R.C., Prame, W.K.B.N. and Ravindrakumar, G.R. (1987) Arrested charnockite formation in southern India and Sri Lanka. Contrib. Mineral. Petrol., 96, 225-44.

Hapuarachchi, D.J.A.C. (1977) Decarbonation reactions and the origin of vein-graphite in Sri Lanka. J. Nat. Sci. Council Sri Lanka, 5, 29-32.

Hoefs, J. and Frey, M.J. (1976) The isotopic composition of carbonaceous matter in a metamorphic profile of the Swiss Alps. Geochim. Cosmochim. Acta, 40, $945-51$.

Itaya, T. (1981) Carbonaceous material in pelitic schists of the Sanbagawa metamorphic belt in central Shikoku, Japan. Lithos, 14, 215-24.

Jackson, D.H., Mattey, D.P. and Harris, N.B.W. (1988) Carbon isotope compositions of fluid inclusions in charnockites from southern India. Nature, 333, $167-70$.

Jubés, E. and Carbonell, A. (1918) Informe sobre los yacimientos de grafito de la zona de AlmonasterCortegana (Huelva). Bol. Of. Min. Metal. 9, 12, 14, 15, and 16.

Julivert, M., Fontboté, J.M., Ribeiro, A. and Conde, L. (1974) Memoria Explicativa del Mapa Tectónico de la Península Ibérica y Baleares. IGME, Madrid.

Kanaris-Sotiriou, R. (1997) Graphite-bearing peraluminous dacites from the Erlend volcanic complex, Faeroe-Shetland Basin, North Atlantic. Mineral. Mag., 61, 175-84.

Katz, M.B. (1987) Graphite deposits of Sri Lanka: a consequence of granulite facies metamorphism. Mineral. Deposita, 22, 18-25.

Kwiecinska, B. (1980) Mineralogy of natural graphites. Polska Akad. Nauk, Prace Mineral., 67, 5-79.

Lamb, W. and Valley, J.W. (1984) Metamorphism of reduced granulites in low- $\mathrm{CO}_{2}$ vapour-free environment. Nature, 312, 56-8.

Lamb, W. and Valley, J.W. (1985) C-O-H fluid calculations and granulite genesis. Pp. 119-31 in: The Deep Proterozoic Crust in the North Atlantic Provinces (A.C. Tobi and J.L.R. Touret, editors). D. Reidel Publishing Company, Dordrecht, The Netherlands.

Luque, F.J. and Rodas, M. (1999) Constraints on graphite crystallinity in some Spanish fluid-deposited occurrences from different geologic settings. Mineral. Deposita, 34, 215-9.

Luque, F.J., Rodas, M. and Galán, E. (1992) Graphite vein mineralization in the ultramafic rocks of southern Spain: Mineralogy and genetic relationships. Mineral. Deposita, 27, 226-33.

Luque, F.J., Barrenechea, J.F. and Rodas, M. (1993) Graphite geothermometry in low and high temperature regimes: two case studies. Geol. Mag., 130, $501-11$.

Luque, F.J., Pasteris, J.D., Wopenka, B., Rodas, M. and
Barrenechea, J.F. (1998) Natural fluid-deposited graphite: Mineralogical characteristics and mechanisms of formation. Amer. J. Sci., 298, 471-98.

Luque, F.J., Rodas, M. and Barrenechea, J.F. (1999) Graphite deposits in southern Spain: Role of carbon isotopes in defining genetic models. Pp. 1117-20 in: Mineral Deposits: Processes to Processing, Vol. 2 (C.J. Stanley, editor). A.A. Balkema, Rotterdam.

Mattey, D.P. (1987) Carbon isotopes in the mantle. Terra Cognita, 7, 31-7.

Munhá, J., Oliveira, J.T., Ribeiro, A., Oliveira, V., Quesada, C. and Kerrick, R. (1986) Beja-Acebuches ophiolite: Characterization and geodynamic significance. Maleo, 2, 31.

Naraoka, H., Ohtake, M., Maruyama, S. and Ohmoto, H. (1996) Non-biogenic graphite in 3.8-Ga metamorphic rocks from the Isua district, Greenland. Chem. Geol., 133, 251-60.

Newton, R.C., Smith, J.V. and Windley, B.F. (1980) Carbonic metamorphism, granulites and crustal growth. Nature, 288, 45-50.

Pasteris, J.D. and Luque, F.J. (1997) Why is the graphite in large epigenetic deposits of uniformly high crystallinity?. Geol. Soc. Amer., Abst. with Prog. 28, A-91.

Poulson, S.R. (1996) Equilibrium mineral-fluid stable isotope fractionation factors in graphitic metapelites. Chem. Geol., 131, 207-17.

Quesada, C., Fonseca, P.E., Munhá, J., Oliveira, J.T. and Ribeiro, A. (1994) The Beja-Acebuches ophiolite (Southern Iberia Variscan fold belt). Geological characterization and geodynamic significance. Bol. Geol. Min., 105, 3-49.

Radhika, U. P., Santosh, M. and Wada, H. (1995) Graphite occurrences in Southern Kerala: Characteristics and genesis. J. Geol. Soc. India, 45, 653-66.

Rumble, D., Duke, E.F. and Hoering, T.C. (1986) Hydrothermal graphite in New Hampshire: Evidence of carbon mobility during regional metamorphism. Geology, 14, 452-5.

Santosh, M. and Wada, H. (1993a) Microscale zonation in graphite crystals: Evidence for chanelled $\mathrm{CO}_{2}$ influx in granulites. Earth Planet. Sci. Lett., 119, $19-26$.

Santosh, M. and Wada, H. (1993b) A carbon isotope study of graphites from the Kerala Khondalite Belt, southern India: Evidence for $\mathrm{CO}_{2}$ infiltration in granulites. J. Geol., 101, 643-51.

Satish-Kumar, M. and Santosh, M. (1998) A petrological and fluid inclusion study of calc-silicatecharnockite associations from southern Kerala, India: implications for $\mathrm{CO}_{2}$ influx. Geol. Mag. 135, 27-45.

Schidlowski, M., Appel., P.W.U., Eichmann, R. and Junge, C.E. (1979) Carbon isotope geochemistry of 
the $3.7 \times 10^{9}$-yr-old Isua sediments, West Greenland: implications for the Archean carbon and oxygen cycles. Geochim. Cosmochim. Acta, 43, 189-99.

Schoell, M. and Wellmer, F.-W. (1981) Anomalous ${ }^{13} \mathrm{C}$ depletion in early Precambrian graphites from Superior Province, Canada. Nature, 290, 696-9.

Shengelia, D.M., Akhvlediani, R.A. and Ketskhoveli, D.N. (1979) The graphite geothermometer. Dokl. Acad. Nauk SSSR, 235, 132-4.

Silva, K.K.M.W. (1987) Mineralization and wall-rock alteration at the Bogala graphite deposit, Bulathkohupitiya, Sri Lanka. Econ. Geol., 82, $1710-22$.

Tagiri, M. (1981) A measurement of the graphitizing degree by the X-ray powder diffractometer. J. Japan. Assoc. Min. Petr. Econ. Geol., 76, 345-52.

Touret, J.R.L. (1971) Le facies granulite en Norvege meridionale. II: Les inclusions fluids. Lithos, 4, 423-6.

Vry, J., Brown, P.E., Valley, J.W. and Morrison, J. (1988) Constraints on granulite genesis from carbon isotope compositions of cordierite and graphite. Nature, 332, 66-8.

Wada, H. and Santosh, M. (1995) Stable isotopic characterization of metamorphic fluid processes in the Kerala Khondalite Belt, south India. Mem. Geol. Soc. India, 34, 161-72.

Wada, H., Tomita, T., Matsuura, K., Iuchi, K., Ito, M. and Morikiyo, T. (1994) Graphitization of carbonaceous matter during metamorphism with references to carbonate and pelitic rocks of contact and regional metamorphisms, Japan. Contrib. Mineral. Petrol., 118, 217-28.

Weis, P.L., Friedman, I. and Gleason, J.P. (1981) The origin of epigenetic graphite: evidence from isotopes. Geochim. Cosmochim. Acta, 45, 2325-32.

Yardley, B.W.D. and Valley, J.W. (1997) The petrologic case for a dry lower crust. J. Geophys. Res., 102(B6), $12173-85$.

[Manuscript received 23 March 1999:

revised 21 January 2000] 